\title{
Factors Affecting the Behaviour in Integrating Google Meet Among Malaysian Primary ESL Teachers During Covid-19 Pandemic
}

\author{
Winson Eng Wei Siang \\ Sekolah Jenis Kebangsaan Cina Ladang Grisek, Johor, Malaysia \\ Maslawati Mohamad \\ Faculty of Education, Universiti Kebangsaan Malaysia, 43600 Bangi, Selangor, Malaysia
}

\begin{abstract}
The unsought Covid-19 pandemic has wreaked havoc in Malaysia's education system, particularly at primary levels. Due to this, schools have been commanded to close immediately by the Ministry of Education (MOE) and Malaysian primary English as a Second Language (ESL) teachers have to conduct their teaching virtually via Google Meet under the government's policy, where all teachers are provided with a Gmail address. The use of Google Meet is not well studied not only in primary schools, but also in the local environment. Therefore, this quantitative research was embarked to look into the factors that influence the integration of Google Meet among primary ESL teachers. Participants $(n=123)$ were selected through purposive sampling based on their teaching option (TESL optionists and non-TESL optionists), teaching ESL in primary schools $(n=12)$ located in Pasir Gudang, Johor, Malaysia. A 5-point Likert scale survey questionnaire adapted from previous studies was used. The factors of perceived usefulness and perceived ease of use towards the use of behaviour in integrating Google Meet were testified. The main findings in descriptive statistics indicated that majority of the primary ESL teachers have shown a positive attitude towards the use of Google Meet. However, some respondents remarkably noted that school administrators should render necessary assistance. The findings of this study could provide better insights for English teachers and school authority on the measures to integrate Google Meet in the teaching and learning of English at primary schools. If Google Meet is well integrated, pupils will benefit from this platform.
\end{abstract}

Index Terms - Covid-19 Pandemic, Malaysian Primary English as a Second Language (ESL)Teachers, Google Meet (GM), perceived usefulness, perceived ease of use

\section{INTRODUCTION}

The sophisticated time-line of today's world has proven that one cannot elude from the change in globalisation (Muhamad Khairul, Airil Haimi, Ahmad Ariffuddin, Muhammad Anwar \& Nurul Nadiah, 2019). Educators of English as a Second Language (ESL) have to bolster their teaching strategies in order to meet its requirement (Ulla, 2018). Since late December 2019, a novel, developing corona virus has been identified, alias Covid-19. It acts as an infectious agent and is often characterised based on the severity of the disease, whether mild, acute or life-threatening (Bragazzi, Mansour, Bonsignore \& Ciliberti, 2020). This circumstance serves as a transformational motivator for primary ESL teachers to migrate from physical classroom to online education, considering the prevalence of virtual ESL teaching and learning as a result of current educational and curriculum policy trends (Bailey, 2020). Mokhtar, Nor Azilah and Ameer (2020) allude that the barb of Covid-19 has compelled educational institutions around the globe to halt their operations in a flash. Bozkurt and Sharma (2020) claim that global school and university closures have impacted more than 1.5 billion learners of all ages, amounting to approximately $90 \%$ of all learners. Many researchers have also stated that such a situation has urged the idea of virtual teaching and learning to become more crucial (Azilah \& Ameer, 2020; Noor Mohammad, 2017). As a result, virtual ESL teaching and learning during the onset of Covid-19 pandemic has become a turning point for both primary ESL teachers and learners in the domestic context. In this study, the local context refers to Malaysia.

Gilakjani (2017) as well as Solanki and Shyamleel (2012) define virtual teaching as one teaching strategy that is experienced by utilising computer-mediated technology, with the presence of Internet connection and can take place within and outside educational institutions. The emergence of numerous video conferencing services such as Google Meet (GM), Zoom and Microsoft Teams (Singh, Singh, Ong, Thambu, Yusoff, Moneyam \& Abdullah, 2020) has served as an open ground for both ESL educators and learners to transport ideas, knowledge and information. In this particular study, GM has been selected due to the local government's policy where all educators are provided with the Ministry of Education (MOE) account in Google Mail (Gmail). Essentially, GM is a complimentary application consisting of several features such as chatroom, activities, polls, breakout rooms and jamboard that offers ESL educators smooth experiences in conducting their lessons. 
The impacts of Covid-19 have, to a greater extent, brought vast educational changes in the Malaysian scenario (Azilah \& Ameer, 2020). This robust reformation has by virtue made the virtual ESL teaching and learning development more tedious and demanding, especially in the local context. Supported by Ali, Uppal and Gulliver (2017), Covid-19 pandemic brings about four major obstacles in the implementation of virtual teaching and learning, namely technology, individual, pedagogy and enabling conditions. To elaborate further, both ESL educators and learners encounter multitude issues pertaining to the integration of GM owing to a number of reasons such as unsteady Internet connection and attention restoration (Min, Shi \& Yang, 2020). Moreover, ESL learners' low level of readiness has indicated the failure of GM during the pandemic period as they are not entirely prepared (Siti, Ali, Ondrej, Petra \& Ngoc, 2020). Tamin and Mohamad (2020) also reflect that ESL teachers are not confident enough to handle the new virtual teaching and learning mode as they are not well-equipped with the technological skills. On top of that, there has been a lack of studies suggesting the success of integrating GM in Malaysia, specifically at primary levels (Ironsi, 2021; Khairi, Faridah, Norsiah \& Zaki, 2021). Nevertheless, some international researchers have proven otherwise (Putu, Ely \& Ninik, 2021; Silviska \& Latifah, 2020).

Hence, in an attempt to reduce the literature gap, the researchers' aim was to identify the factors influencing the integration of GM in the teaching of English language at primary schools during Covid-19 pandemic. Thus, the researchers' aim was to answer the following research question.

RQ1: What are the factors influencing the behaviour in integrating Google Meet among English teachers at primary schools?

\section{LITERATURE REVIEW}

The presence of Covid-19 pandemic and growing pattern of electronic devices and internet taking place in the current world have driven ESL educators to keep abreast with technology advancements in due course, particularly in the context of education (Singh et al., 2020). Despite the laborious challenges faced by ESL educators, the infusion of technology does bring positive impacts in language teaching and learning, benefiting both ESL educators and learners (Sornasekaran, Mohammed \& Amidi, 2020; Muhamad Khairul et al., 2019). Thus, the conventional approach of ESL teaching via face-to-face is no longer perceived as the sole teaching approach in the eye of education domain. Based on these changes, it is imperative for primary ESL teachers to take initiatives to master and equip themselves with fundamental Information, Communication and Technology (ICT) skills (Ironsi, 2021; Singh et al., 2020). Following these series of statements, the following subsection will explore the related works of this study.

\section{A. Concept of Google Meet among Malaysian Primary ESL Teachers}

According to Grapragasem, Krishnan and Azlin (2014), primary ESL teachers should play a multifaceted role in order to integrate technology with instructional practices. Hence, video conferencing applications have recently become more of a requirement than a desire (Singh \& Awasthi, 2020). Consequently, primary ESL teachers have a plethora of platforms from which to choose. Zoom, Line, Microsoft Teams, GoToMeetings and GM are just a few of the video conferencing platforms available due to their currency and availability.

Several past studies have been conducted in response to GM during the period of Covid-19 pandemic. In the context of ESL, Kohnke and Moorhouse (2020) justify that learners can use language productively in their learning using the 'breakout room' feature available in GM. Lo and Melor (2021) agree that collaborative learning can be enhanced because learners work best through brainstorming, sharing and exchanging ideas among peers using Google Docs and GM. 'Jamboard' is another titillating medium that can be found in GM as well. According to Olena (2021), 'Jamboard' intrigues learners' through collaboration, challenge and unleashing their creative abilities. Once the time in breakout rooms end, learners return to the open class discussion and deliver their presentations. In effect, the optimal use of such features could tackle the needs of Generation $\mathrm{Z}$ including short attention span, self-assertiveness and being high-tech savvy (Kohnke \&Moorhouse, 2020).

Other studies have also shown positive results in the usage of GM. According to Rizal (2021), willingness to learn is to be the highest motivator among $7^{\text {th }}$ grade learners where synchronous and asynchronous approaches are applied to enhance their competence and motivation via GM. Another study by Putu, Ely and Ninik (2021) implies that learners portray high level of confidence in expressing their thoughts when the educator presents comic strips using GM platform. Additionally, GM has proven to be an effective platform to conduct vocal learning through some vocal techniques, including breathing, diction and articulation (Silviska \& Latifah, 2020). With GM as a learning medium, the indicators of success have been reached in the second cycle (Silviska \& Latifah, 2020).

Anshari, Almunawar, Shahrill, Wicaksono and Huda (2017) mention that the Internet has become as one of the vital means in the areas of learning and research for both primary ESL teachers and learners. Siti et al. (2020) are in the same wavelength as Anshari et al. (2017), elucidating that virtual teaching and learning allow primary ESL teachers to create materials for their respective sessions, to channel philosophies and concepts to the learners as well as to regulate the curricula prescribed by the local ministry. Reciprocating the preceding justifications in this undertaken study, various beneficial characteristics have been highlighted by Silviska and Latifah (2020): (1) it is free to download and use; (2) the quota usage is lower than other video communicating applications; (3) it has no time limit, so the duration of use is longer; (4) it is simple to operate or function and (5) the email is already connected with Gmail. In Malaysia, the 
Ministry of Education (MOE) provides all primary ESL teachers with authorised email addresses (Gmail). Thus, based on the literature aforementioned, the researchers have chosen GM for the purpose of this study.

\section{B. Underpinning Theories}

Two underlying theories that are related to this study are connectivism theory and social constructivist theory.

\section{Connectivism Theory}

Connectivism, as defined by Mattar (2018), is an appropriate theory for the digital age, in which action and information are retrieved beyond one's basic understanding. An instance portrayed by Rusmawan, Trianasari and Wilujeng (2021) shows that using GM to create comic strips gives learners the confidence to voice their ideas, pique their curiosity and is cost effective. On a similar viewpoint, Agung, Nurfina, Paidi, Tyasmiarni and Kusdianto (2020) extrapolate that in lecturing learning methodologies in elementary schools, GM has a major impact on building knowledge and learners' learning results, particularly primary school pupils. Hence, GM is a user-friendly platform that allows both primary ESL teachers and learners to express their ideas and notions.

Some of the tenets spelled out by Corbett, Fraizer, Madjidi and Sweeney (2018) review the theory of connectivism as follows: (a) teaching and learning are based on a variety of perspectives, beliefs and aspects; (b) teaching-learning is a process that connects many specialised modes to information sources; (c) the goal of all teaching-learning activities is to provide learners with current information; (d) the ability to inquire further is critical and (e) non-human appliances may be used to teach and learn. Adversely, Corbett and Spinello (2020) conclude four major elements in their research. They are autonomy, connectedness, diversity and openness. Nonetheless, this undertaken study takes into account three key concepts suggested by Corbett and Spinello (2020) that are autonomy, connectedness and openness. Diversity, in this case, is not prevalent as the researchers aim to investigate the behaviour of teachers instead of learners. In gist, connectivism theory is relevant in the study - to identify the factors influencing the behaviour in integrating Google Meet among English teachers at primary schools.

\section{Social Constructivist Theory}

In recent years, social constructivist theory has emerged as an instrumental grounded paradigm in education, leave alone its significant intellectual impact on pedagogical progress (Aljohani, 2017). Remarkably, Suhendi and Purwarno (2018) allude that social constructivist theory entails learners shuld be the active subject in developing their knowledge from their interactions with the environment particularly more knowledgeable others. A research conducted by Agung et al. (2020) exemplifies that GM has an enormous impact on building knowledge and learning outcomes between primary ESL teachers and learners. According to Mohammed, Mohamed and Amel (2018), collaborative learning can be formed and promoted with the use of GM. This is typical when ESL teachers assign a topic and have their learners discussed in their respective breakout rooms, prior to pair or group presentations (Mohammed, Mohamed \& Amel, 2018). Parallel to that, the most common benefit in using GM for virtual teaching and learning is that primary ESL teachers allow rooms for conversations and social exchanges via the chatbox service (Hiranrithikorn, 2019). In effect, primary ESL teachers are able to administer quizzes or presentations using the platform of GM so as to promote learners' collaborative engagement in language learning.

In this particular theory, two precepts as illuminated by Korpershoek, Harms, de Boer, van Kuijk and Doolaard (2014) are applied in this study. For one, primary ESL teachers should schedule and exercise instructions in a systematic order (Korpershoek et al., 2014). On this point, Suhendi and Purwarno (2018) explain that primary ESL teachers must be able to organise their teaching materials in a methodical manner in order to alleviate learners' doubts and provide rational clarifications through group work activities. The latter precept emphasised by Korpershoek et al. (2014) is to uplift learners' involvement in language learning. Several researchers have come to a consensus that when assigning academic activities, primary ESL teachers should solicit diverse approaches to present materials, so that learners' contribution throughout the lesson can be invigorated (Suhendi \& Purwarno, 2018; Aljohani, 2017). This theory is relevant to this current study as it gives ideas to primary ESL teachers the effective measures to energise their instructional strategies, and pedagogical approaches.

\section{Technology Acceptance Model 3.0}

For the purpose of this study, TAM 3.0 has been used as a foundation to identify and understand factors predicting the utilisation of GM in the teaching of English among Malaysian primary ESL teachers during Covid-19 pandemic. It also functions as a guiding academic model to examine the factors influencing the behaviour in integrating Google Meet among English teachers at primary schools. According to the experts (Venkatesh \& Bala, 2008), TAM 3.0 is designed to predict individual acceptance and use of new technological systems. In this model, perceived usefulness (PU) and perceived ease of use (PEOU) are the dominating principles. Nur Siyam (2019) defines PU as the degree to which a user's belief in the application of a given system or technology will increase his or her job performance. On the other hand, Mikusa (2015) entails PEOU as the degree to which an individual believes that using a certain technology will be painless. Figure 1 provides a summary of the model. 


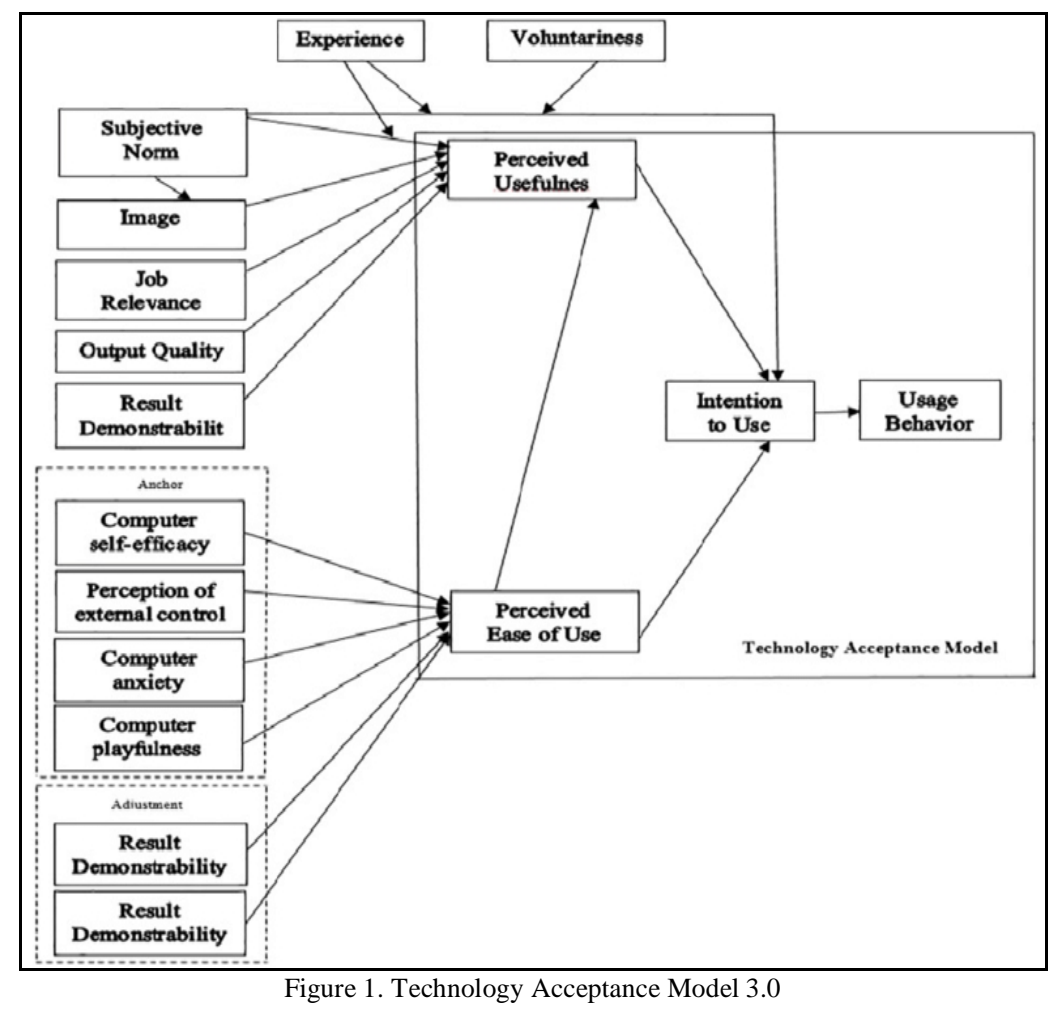

Figure 1 delineates the diagram of TAM 3.0 adapted from Venkatesh and Bala (2008). There are nine external constructs under PU, namely PU, PEOU, subjective norm, experience, image, job relevance, output quality, voluntariness and result demonstrability. Conversely, PEOU describes six distinctive conditions which are computer self-efficacy, perception of external control, computer anxiety, computer playfulness, perceived enjoyment and objective usability. Apart from the aspect of technology, there is a library of research indicating the suitability of such a model to analyse the present investigation (Al-Maroof, Alshurideh, Salloum, Alhamad \& Gaber, 2021; Purwanto \& Tannady, 2020; Nur Siyam, 2019; Rahman, Yunus \& Hashim, 2019; Weng, Yang, Ho \& Su, 2018, Teeroovengadum, Heeraman \& Jugurnath, 2017; Mikusa, 2015; Venkatesh \& Bala, 2008). Ultimately, the variables help to attain and predict the best single predictor of actual usage, which is behavioural intention to use the proposed platform. The researcher intended to investigate these two factors (Perceived Usefulness and Perceived Eae of Use) influencing the behaviour in integrating Google Meet among English teachers at primary schools.

\section{Methodology}

This empirical study took a quantitative approach to identify the factors affecting the behaviour in integrating Google Meet in the teaching of English among primary ESL teachers during Covid-19 pandemic. Figure 2 demonstrates the interface of GM. The researchers employed a survey questionnaire method to obtain data based on a 5-point Likert scale (1 - Strongly Agree, 2 - Disagree, 3 - Neutral, 4 - Agree \& 5 - Strongly Agree). A purposive sampling was applied and a total of 123 primary ESL teachers from Pasir Gudang district was chosen to be the respondents in this study. According to Krejcie and Morgan (1970), a minimum of 123 samples was adequate for this research given the total number of 175 . Similarly, Pasir Gudang was chosen due to its geographical location, unstable internet connection and limited research done on primary levels. 


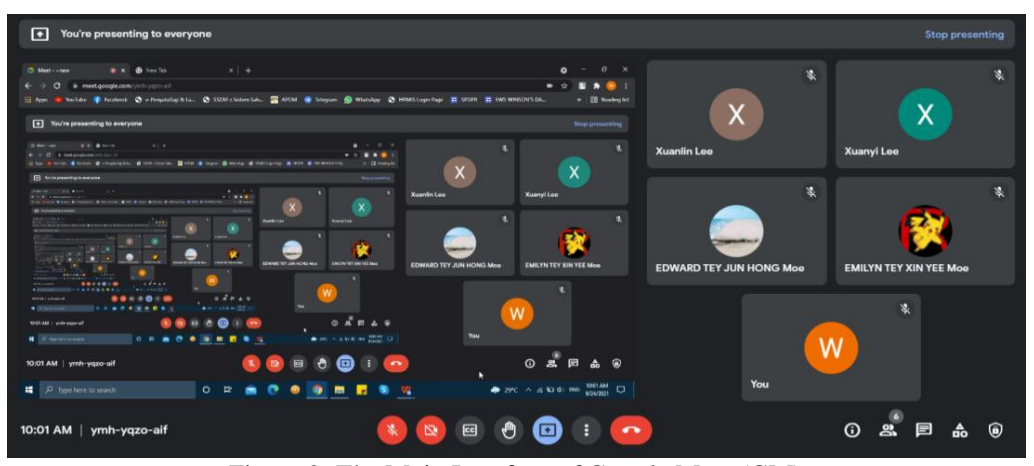

Figure 2. The Main Interface of Google Meet (GM)

Figure 2 shows the portrayal of GM once primary ESL teachers and learners have signed in using the email provided by the MOE. It is a relatively user-friendly tool to use as there are several features available that allow communication and interaction to take place between teachers, learners and among the learners. Some of the options include captions, sharescreen, chatbox, change layout, activities and others. Figure 3 exhibits the function of the chatbox whereas Figure 4 displays other activities made convenient for primary ESL teachers to conduct their English lessons.

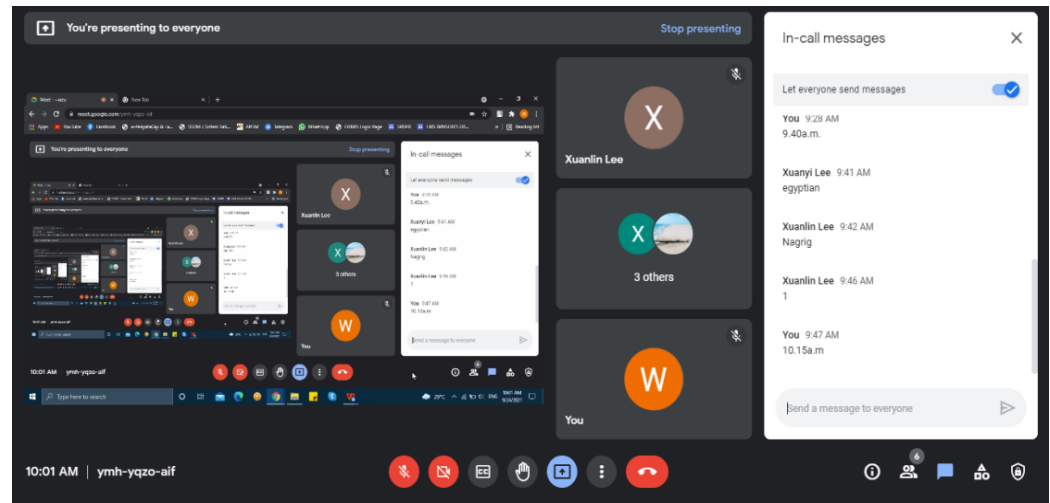

Figure 3. The Feature of Chatbox on Google Meet (GM)

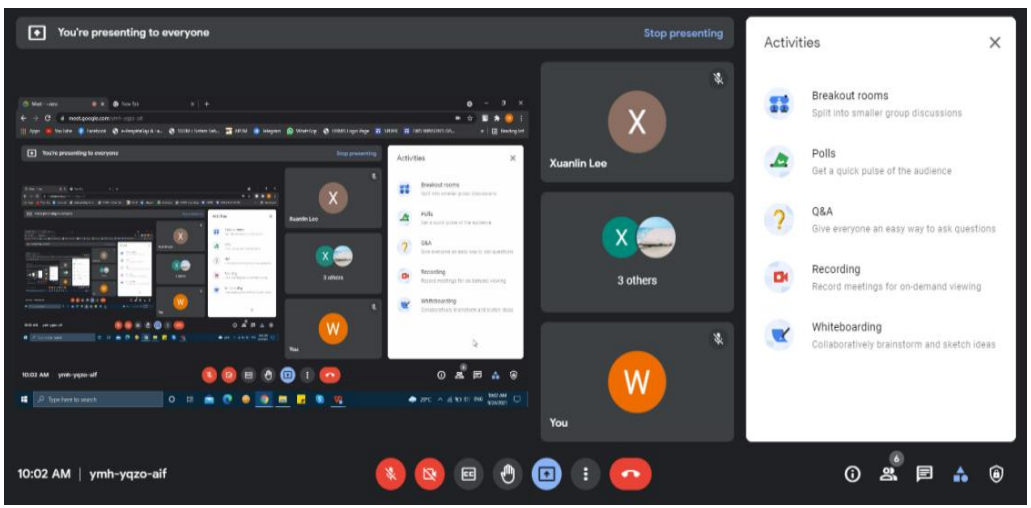

Figure 4. Other Related Activities Available on Google Meet (GM)

The questionnaire consisted of General Profile and 3 sections. Items on General Profile segment were intended to elicit background information about the participants. On the other hand, a sum of 30 items was used to collect quantitative data from the respondents. Section A comprises 14 items pertaining to PU according to 9 variables (PU, PEOU, SN, IMG, EXP, REL, OUT, VOL and RES). Section B consists of 13 items concerning PEOU in accordance with 6 variables (CSE, PEC, CANX, CPLAY, ENJ and OBJ), while Section C encompasses 3 items on attitude. All items were adapted from various sources (Al-Maroof et al., 2021; Purwanto \& Tannady, 2020; Rahman, Yunus \& Hashim, 2019; Teeroovengadum, Heeraman \& Jugurnath, 2017; Mikusa, 2015; Venkatesh \& Bala, 2008). A pilot study was administered. The Cronbach-Alpha values for PU and PEOU were 0.817 and 0.753 respectively, illustrating that all the items in questionnaire were reliable. Subsequently, the data were analysed and interpreted descriptively using frequency and percentage. Table 1 demonstrates the summary of the questionnaire. 
TABLE 1

SUMMARY OF THE QUESTIONNAIRE

\begin{tabular}{|c|c|c|}
\hline No. & Construct & Category \\
\hline 1 & I can enhance my English teaching quality using Google Meet during Covid-19. & PU \\
\hline 2 & I find Google Meet useful in conducting my English lessons during Covid-19. & PU \\
\hline 3 & I find it easy to teach English using Google Meet during Covid-19. & PEOU \\
\hline 4 & I can make my pupils' interaction more engaging using Google Meet during Covid- 19. & PEOU \\
\hline 5 & $\begin{array}{l}\text { I find the administrators have been helpful in utilising Google Meet to teach English during Covid- } \\
19 .\end{array}$ & SN \\
\hline 6 & My school has given its full support on the use of Google Meet to teach English during Covid-19. & $\mathrm{SN}$ \\
\hline 7 & I have high self-esteem using Google Meet to teach English during Covid- 19. & IMG \\
\hline 8 & I voluntarily use Google Meet to teach English during Covid-19. & VOL \\
\hline 9 & I find Google Meet important in the teaching of English during Covid-19. & REL \\
\hline 10 & I find Google Meet relevant in the teaching of English during Covid-19. & REL \\
\hline 11 & I can understand the functions of Google Meet very well. & EXP \\
\hline 12 & I can share my experiences using Google Meet to teach English with my colleagues during Covid-19. & EXP \\
\hline 13 & I can teach English smoothly using Google Meet during Covid-19. & OUT \\
\hline 14 & I rate the results from Google Meet in the teaching of English to be excellent during Covid- 19 . & OUT \\
\hline 15 & $\begin{array}{l}\text { I have no difficulties telling others about pupils' results when using Google Meet ito teach English } \\
\text { during Covid-19. }\end{array}$ & \multirow{2}{*}{ RES } \\
\hline 16 & I can observe my learners' interaction using Google Meet during Covid-19. & \\
\hline 17 & $\begin{array}{l}\text { I could use Google Meet to teach English if someone had already taught me how to do it during } \\
\text { Covid-19. }\end{array}$ & CSE \\
\hline \multirow{2}{*}{$\begin{array}{l}18 \\
19\end{array}$} & I have full control over the use of Google Meet to teach English during Covid-19. & PEC \\
\hline & I have the resources available to use Google Meet to teach English during Covid-19. & PEC \\
\hline 20 & I am not scared at all using Google Meet to teach English during Covid-19. & CANX \\
\hline 21 & I feel uncomfortable using Google Meet to teach English during Covid-19. & CANX \\
\hline 22 & I am more creative when using Google Meet to teach English during Covid-19. & CPLAY \\
\hline 23 & I can improve my spontaneity when using Google Meet to teach English during Covid-19. & CPLAY \\
\hline 24 & I find it enjoyable to using Google Meet to teach English during Covid-19. & ENJ \\
\hline 25 & I always use Google Meet to teach English during Covid-19. & OBJ \\
\hline 26 & I sometimes use Google Meet to teach English during Covid-19. & OBJ \\
\hline 27 & I never use Google Meet to teach English during Covid-19. & OBJ \\
\hline 28 & I am excited to use Google Meet to teach English during Covid-19. & ATT \\
\hline 29 & I get anxious when I do not have the Internet connection available to me. & ATT \\
\hline 30 & I believe that using Google Meett to teach English is a good idea during Covid-19. & ATT \\
\hline
\end{tabular}

\section{A. Validity}

The researchers had taken necessary measures to validate the items of the questionnaire since the items were adapted from various sources (Al-Maroof et al., 2021; Purwanto \& Tannady, 2020; Rahman, Yunus \& Hashim, 2019; Teeroovengadum, Heeraman \& Jugurnath, 2017; Mikusa, 2015; Venkatesh \& Bala, 2008). In order to do so, the researchers had administered a pilot study on 14 July 2021. The questionnaire was distributed to 20 primary school teachers who are currently teaching English subject in schools. These teachers were exempted from the list of schools in the actual research. Similarly, the researchers had consulted three experts to get their feedback and insights. Experts, in this case, refer to those who have published or worked in the field of education. Table 2 is a summary of the experts' profiles.

TABLE 2

EXPERT'S PROFESSIONAL BACKGROUND

\begin{tabular}{|c|c|c|c|}
\hline Name & & Academic Background & $\begin{array}{c}\text { Teaching } \\
\text { Experiences }\end{array}$ \\
\hline Expert 1 & • & $\begin{array}{l}\text { Bachelor of Arts in Japanese Language \& Area Studies, from Tokyo University of } \\
\text { Foreign Studies, Japan } \\
\text { Master of Education in Management \& Administration in Education, from USM } \\
\text { PhD in Adult Education \& Professional Development, from UKM }\end{array}$ & 28 years \\
\hline Expert 2 & $\begin{array}{l}\bullet \\
\bullet \\
\bullet \\
\bullet \\
\bullet\end{array}$ & $\begin{array}{l}\text { B.A. (Hon), from UM } \\
\text { M. Ed in Testing \& Evaluation, from UM } \\
\text { Ph.D in Evaluation and Assessment Education, from UKM } \\
\text { Exemplary lecturer from } 1998 \\
\text { Member of Senate IPGM } 2011-2016\end{array}$ & 32 years \\
\hline Expert 3 & $\bullet$ & $\begin{array}{l}\text { B.Ed in Education (TESL) from UITM } \\
\text { M.Ed in Education (TESL) from UTM }\end{array}$ & 30 years \\
\hline
\end{tabular}

\section{B. Reliability}

On the aspect of reliability, Cronbach Alpha was used to measure the internal-consistency of the questionnaire through the score of the Likert Scale obtained from the pilot test. The data of the pilot study were analysed using the 
SPSS Software Version 23. The coefficient of Perceived Usefulness (PU) was 0.817 (strong) while Perceived Ease of Use (PEOU) was 0.753 (strong). The Cronbach Alpha values for each construct are displayed in Table 3.

TABLE 3

CRONBACH ALPHA RESULT

\begin{tabular}{lccc}
\hline \multicolumn{1}{c}{ Construct } & No. of Items & Cronbach Alpha Value & Indication \\
\hline Perceived usefulness & 14 & 0.817 & Strong \\
Perceived ease of use & 13 & 0.753 & Strong \\
\hline
\end{tabular}

\section{RESULTS AND FINDINGS}

The results and findings of this undertaken study were tabulated and explained in this section. The following segments entailed a summary of the identified factors affecting the behavioural acceptance in the utilisation of GM among Malaysian primary ESL teachers during Covid-19 pandemic.

\section{A. Normality Test}

Figure 5 and 6 represent the normality test of factors regarding PU and PEOU towards the integration of GM for English lessons at primary schools. According to the figures, both histograms presented a bell curve respectively. Thus, it could be deduced that the sample data distributions for both factors were normal because they fulfilled the normality criteria (Mishra, Pandey, Singh, Gupta, Sahu \& Keshri, 2019).

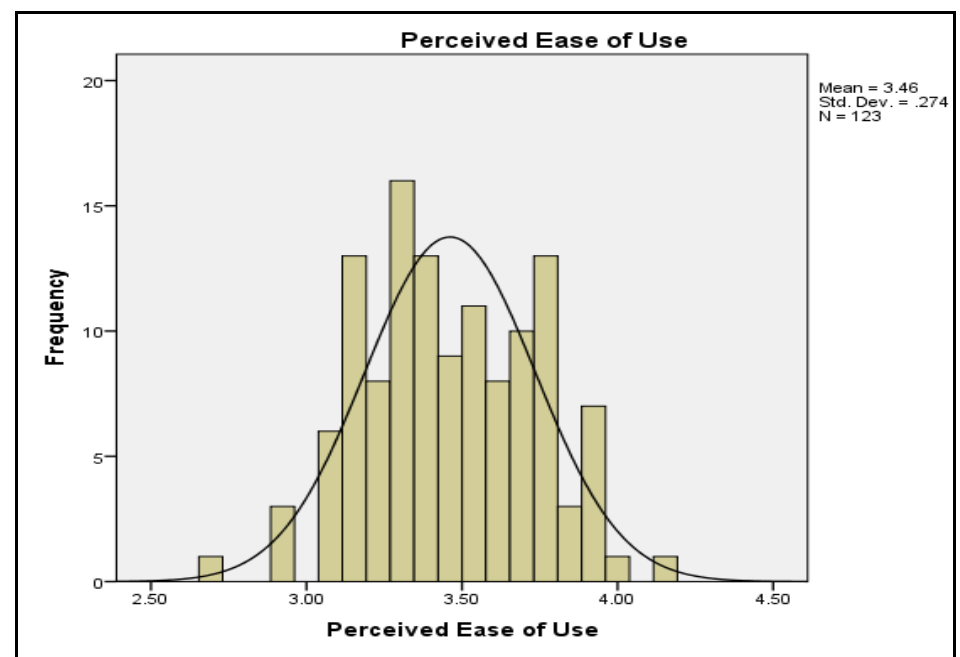

Figure 5. Perceived Usefulness

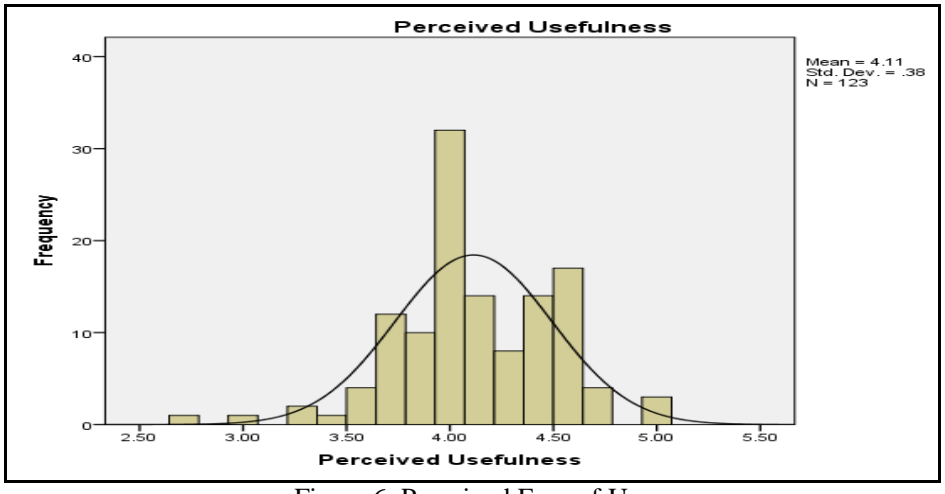

Figure 6. Perceived Ease of Use

\section{B. Perceived Usefulness (PU) towards the Integration of Google Meet (GM)}

Based on the survey, the data regarding perceived usefulness (PU) towards the behaviour in integrating GM among English teachers at primary schools during Covid-19 pandemic were recorded as shown in Table 4. 
TABLE 4

PERCEIVED UsEFUlNESS (PU) TOWARDS THE INTEGRATION OF GOOGLE MEET (GM)

\begin{tabular}{|c|c|c|c|c|c|}
\hline Statements & SD & D & $\mathbf{N}$ & $\mathbf{A}$ & $\mathbf{S A}$ \\
\hline I can enhance my English teaching quality & 0 & 0 & 7 & 91 & 25 \\
\hline using Google Meet during Covid-19. & $0 \%$ & $0 \%$ & $5.7 \%$ & $74 \%$ & $20.3 \%$ \\
\hline I find Google Meet useful in conducting my & 0 & 1 & 6 & 89 & 27 \\
\hline English lessons during Covid-19. & $0 \%$ & $0.8 \%$ & $4.9 \%$ & $72.4 \%$ & $22 \%$ \\
\hline I find the administrators have been helpful in & 1 & 3 & 26 & 73 & 20 \\
\hline $\begin{array}{l}\text { utilising Google Meet to teach English during } \\
\text { Covid-19. }\end{array}$ & $0.8 \%$ & $2.4 \%$ & $21.1 \%$ & $59.3 \%$ & $16.3 \%$ \\
\hline My school has given its full support on the use & 0 & 1 & 30 & 69 & 23 \\
\hline $\begin{array}{l}\text { of Google Meet to teach English during } \\
\text { Covid-19. }\end{array}$ & $0 \%$ & $0.8 \%$ & $24.4 \%$ & $56.1 \%$ & $18.7 \%$ \\
\hline $\begin{array}{l}\text { I have high self-esteem using Google Meet to } \\
\text { teach English during Covid-19. }\end{array}$ & $\begin{array}{c}0 \\
0 \%\end{array}$ & $\begin{array}{c}0 \\
0 \%\end{array}$ & $\begin{array}{c}17 \\
13.8 \%\end{array}$ & $\begin{array}{c}82 \\
66.7 \%\end{array}$ & $\begin{array}{c}24 \\
19.5 \%\end{array}$ \\
\hline I voluntarily use Google Meet to teach English & 0 & 0 & 8 & 85 & 30 \\
\hline during Covid-19. & $0 \%$ & $0 \%$ & $6.5 \%$ & $69.1 \%$ & $24.4 \%$ \\
\hline I find Google Meet important in the teaching & 0 & 0 & 2 & 76 & 45 \\
\hline of English during Covid-19. & $0 \%$ & $0 \%$ & $1.6 \%$ & $61.8 \%$ & $36.6 \%$ \\
\hline I find Google Meet relevant in the teaching of & 0 & 0 & 3 & 76 & 44 \\
\hline English during Covid- 19. & $0 \%$ & $0 \%$ & $2.4 \%$ & $61.8 \%$ & $35.8 \%$ \\
\hline I can understand the functions of Google Meet & 0 & 2 & 6 & 97 & 18 \\
\hline very well. & $0 \%$ & $1.6 \%$ & $4.9 \%$ & $78.9 \%$ & $14.6 \%$ \\
\hline I can share my experiences using Google Meet & 0 & 0 & 8 & 94 & 21 \\
\hline $\begin{array}{l}\text { to teach English with my colleagues during } \\
\text { Covid-19. }\end{array}$ & $0 \%$ & $0 \%$ & $6.5 \%$ & $76.4 \%$ & $17.1 \%$ \\
\hline I can conduct my English lesson smoothly & 0 & 1 & 3 & 92 & 27 \\
\hline using Google Meet during Covid-19. & $0 \%$ & $0.8 \%$ & $2.4 \%$ & $74.8 \%$ & $22 \%$ \\
\hline I rate the results from Google Meet in the & 0 & 1 & 18 & 90 & 14 \\
\hline $\begin{array}{l}\text { teaching of English to be excellent during } \\
\text { Covid-19. }\end{array}$ & $0 \%$ & $0.8 \%$ & $14.6 \%$ & $73.2 \%$ & $11.4 \%$ \\
\hline I have no difficulties telling others about & 0 & 2 & 10 & 84 & 27 \\
\hline $\begin{array}{l}\text { pupils' results when using Google Meet to } \\
\text { teach English during Covid-19. }\end{array}$ & $0 \%$ & $1.6 \%$ & $8.1 \%$ & $68.3 \%$ & $22 \%$ \\
\hline I can observe my learners' interaction using & 1 & 2 & 7 & 79 & 34 \\
\hline Google Meet during Covid-19. & $0.8 \%$ & $1.6 \%$ & $5.7 \%$ & $64.2 \%$ & $27.6 \%$ \\
\hline
\end{tabular}

Based on Table 4, it can be seen that majority of the respondents perceived GM to be useful $(n=116)$, important $(\mathrm{n}=121)$ and relevant $(\mathrm{n}=120)$. Respectively, they agreed that GM is useful in conducting English lessons during Covid19 pandemic (94.4\%), important in the teaching of English during Covid-19 pandemic (98.4\%) and relevant in the teaching of English during Covid-19 pandemic (97.6\%). Despite the fact that GM is crucial and relevant, some of them concurred that school administrators played an instrumental role in rendering assistance, with being helpful ( $\mathrm{n}=93$, $75.6 \%)$ and giving full support $(\mathrm{n}=92,74.8 \%)$.

\section{Perceived Ease of Use (PEOU) towards the Integration of Google Meet (GM)}

The findings regarding perceived ease of use (PEOU) towards the behaviour in integrating GM among English teachers at primary schools during Covid-19 pandemic were demonstrated in Table 5. 
TABLE 5

Perceived EAse Of Use (PEOU) TOWARds The INTEGRATION OF GOOGLE MEeT (GM)

\begin{tabular}{|c|c|c|c|c|c|}
\hline Statements & SD & D & $\mathbf{N}$ & $\mathbf{A}$ & SA \\
\hline \multirow{2}{*}{$\begin{array}{l}\text { I find it easy to teach English using Google } \\
\text { Meet during Covid-19. }\end{array}$} & 0 & 1 & 6 & 92 & 24 \\
\hline & $0 \%$ & $0.8 \%$ & $4.9 \%$ & $74.8 \%$ & $19.5 \%$ \\
\hline \multirow{2}{*}{$\begin{array}{l}\text { I can make my pupils' interaction more } \\
\text { engaging using Google Meet during Covid- } 19 \text {. }\end{array}$} & 0 & 1 & 9 & 88 & 25 \\
\hline & $0 \%$ & $0.8 \%$ & $7.3 \%$ & $71.5 \%$ & $20.3 \%$ \\
\hline \multirow{2}{*}{$\begin{array}{l}\text { I could use Google Meet to teach English if } \\
\text { someone had already taught me how to do it } \\
\text { during Covid-19. }\end{array}$} & 0 & 1 & 30 & 74 & 18 \\
\hline & $0 \%$ & $0.8 \%$ & $24.4 \%$ & $60.2 \%$ & $14.6 \%$ \\
\hline \multirow{2}{*}{$\begin{array}{l}\text { I have full control over the use of Google Meet } \\
\text { to teach English during Covid-19. }\end{array}$} & 0 & 2 & 39 & 69 & 13 \\
\hline & $0 \%$ & $1.6 \%$ & $31.7 \%$ & $56.1 \%$ & $10.6 \%$ \\
\hline \multirow{2}{*}{$\begin{array}{l}\text { I have the resources available to use Google } \\
\text { Meet to teach English during Covid-19. }\end{array}$} & 0 & 0 & 11 & 92 & 20 \\
\hline & $0 \%$ & $0 \%$ & $8.9 \%$ & $74.8 \%$ & $16.3 \%$ \\
\hline \multirow{2}{*}{$\begin{array}{l}\text { I am not scared at all using Google Meet to } \\
\text { teach English during Covid-19. }\end{array}$} & 0 & 2 & 5 & 92 & 24 \\
\hline & $0 \%$ & $1.6 \%$ & $4.1 \%$ & $74.8 \%$ & $19.5 \%$ \\
\hline \multirow{2}{*}{$\begin{array}{l}\text { I feel uncomfortable using Google Meet to } \\
\text { teach English during Covid-19. }\end{array}$} & 78 & 38 & 4 & 3 & 0 \\
\hline & $63.4 \%$ & $30.9 \%$ & $3.3 \%$ & $2.4 \%$ & $0 \%$ \\
\hline \multirow{2}{*}{$\begin{array}{l}\text { I am more creative when using Google Meet to } \\
\text { teach English during Covid-19. }\end{array}$} & 0 & 1 & 9 & 92 & 21 \\
\hline & $0 \%$ & $0 \%$ & $7.3 \%$ & $74.8 \%$ & $17.1 \%$ \\
\hline \multirow{2}{*}{$\begin{array}{l}\text { I can improve my spontaneity when using } \\
\text { Google Meet to teach English during Covid- } \\
19 .\end{array}$} & 0 & 0 & 6 & 92 & 25 \\
\hline & $0 \%$ & $0 \%$ & $4.9 \%$ & $74.8 \%$ & $20.3 \%$ \\
\hline \multirow{2}{*}{$\begin{array}{l}\text { I find it enjoyable to using Google Meet to } \\
\text { teach English during Covid-19. }\end{array}$} & 0 & 0 & 4 & 83 & 36 \\
\hline & $0 \%$ & $0 \%$ & $3.3 \%$ & $67.5 \%$ & $29.3 \%$ \\
\hline \multirow{2}{*}{$\begin{array}{l}\text { I always use Google Meet to teach English } \\
\text { during Covid-19. }\end{array}$} & 1 & 1 & 1 & 74 & 46 \\
\hline & $0.8 \%$ & $0.8 \%$ & $0.8 \%$ & $60.2 \%$ & $37.4 \%$ \\
\hline \multirow{2}{*}{$\begin{array}{l}\text { I sometimes use Google Meet to teach English } \\
\text { during Covid-19. }\end{array}$} & 81 & 35 & 6 & 1 & 0 \\
\hline & $65.9 \%$ & $28.5 \%$ & $4.9 \%$ & $0.8 \%$ & $0 \%$ \\
\hline \multirow{2}{*}{$\begin{array}{l}\text { I never use Google Meet to teach English } \\
\text { during Covid-19. }\end{array}$} & 100 & 19 & 2 & 1 & 1 \\
\hline & $81.3 \%$ & $15.4 \%$ & $1.6 \%$ & $0.8 \%$ & $1 \%$ \\
\hline
\end{tabular}

With reference to Table 5, most respondents replied that GM is easy to use, thus making them more creative and their English lessons more enjoyable. They were $\mathrm{n}=116(94.3 \%), \mathrm{n}=113(91.9 \%)$ and $\mathrm{n}=119(96.8 \%)$ respectively. However, 92 out of 123 respondents replied that they could use GM to teach English if someone had already taught them how to use it during Covid-19 with $74.8 \%$. In addition, $66.7 \%$ of the respondents $(n=82)$ claimed that they have full control over the use of GM to teach English during Covid-19 pandemic. The lowest percentage fell under the statement of 'I feel uncomfortable using GM to teach English during Covid-19' with the percentage of 2.4, where $n=3$.

\section{DISCUSSION}

The findings indicated an overall positive perception of primary ESL teachers towards the integration of GM. PU became the most outstanding factor leading to such promising results. This is in line with several researchers pertaining to relevant studies in this field (Rusmawan, Trianasari \& Wilujeng, 2021; Rizal, 2021; Silviska \& Latifah, 2020). It was evident that a large number of primary ESL teachers viewed GM to be highly important, relevant and useful in conducting their English lessons, particularly in this trying period of Covid-19 pandemic. Moreover, most of them could engage with the learners' interaction via GM. With respect to the theoretical perspective, Mohammed, Mohamed and Amel (2018) imply that the use of GM was able to promote collaborative learning proposed by the social constructivist theory proponents. It was further supported by Singh et al. (2020) claiming that ESL teachers possess adequate knowledge on strategising, implementing, interacting and evaluating learners using this platform. Therefore, due to those elaborated features on GM, primary ESL teachers were eager and demonstrated high enthusiasm in making their English lessons more purposeful and fulfilling.

Apart from that, GM was perceived as easy to use by the majority of primary ESL teachers in Pasir Gudang. As opposed to other video conferencing tools, GM displayed online facilitating features and functions in a more vivid 
manner, resulting in the ease of use by primary ESL teachers (Purwanto \& Tannady, 2020). Undoubtedly, having resources available by the primary ESL teachers serves another advantageous point. This is because Purwanto and Tannady (2020) elude that primary ESL teachers could conduct their lessons effectively using GM due to its userfriendly features like whiteboard, polls and breakout rooms. They could easily post any questions using those features and get responses from the learners. In association with connectivism theory by Corbett et al. (2018), teaching-learning is a process that links many specialised modes to information sources. More so, autonomous learning among learners was generated (Corbett \& Spinello, 2020). Complementary to that, primary ESL teachers found GM to be convenient as they could replicate their pedagogies virtually when conducting their lessons (Gleason \& Heath, 2021). Furthermore, the use of GM enabled primary ESL teachers to allow their learners to run smaller group discussions in a convenient manner. Thus, the use of GM provided opportunities for primary ESL teachers to be more creative and spontaneous, so as to make their English lessons more impactful to the learners.

Last but not least, the exploitation of GM sparkled positive attitude from primary ESL teachers. A high percentage of the teachers $(n=114,92.7 \%)$ agreed that they are excited to use GM to teach English lessons during the pandemic era. One of the most prevailing reasons was flexibility in teaching and learning (Hiranrithikorn, 2019). With the appearance of GM, primary ESL teachers could access teaching-learning, support data and administer their lessons in a ubiquitous manner (Mohammed Saleh, 2019). Al-Maroof, Salloum, Hassanien and Shaalan (2020) also imply that even though teachers and learners were separated physically, course materials and activities could still be distributed and conducted using the virtual way of teaching. Indirectly, this helped primary ESL teachers, who allegedly developed high level of anxiety during Covid-19 pandemic, find GM to be a good platform in language teaching, hence improving learners' learning outcomes (Al-Maroof et al., 2020).

\section{CONCLUSION}

In essence, this paper identified two major factors influencing the behaviour in integrating GM among primary ESL teachers, known as PU and PEOU. The former factor showcased the findings that GM as a video conferencing platform for virtual teaching and learning indeed brought many positive perceptions. The key elements were useful, important and relevant. The latter indicated that GM was easy to use, thus making primary ESL teachers more creative and improving their English lessons to be more enjoyable. In conclusion, GM could be an educational platform for primary ESL teachers to impart knowledge.

This paper could provide insights to school administrators to look into measures to render support and enhance technological skills among primary ESL teachers by encouraging them to enroll into courses or provide the teachers trainings related to GM. Future studies could also look into ESL learners from various levels and geographical locations who benefit from this platform not only in the Malaysian context, but also the global one.

\section{ACKNOWLEDGEMENTS}

This article is funded by Dana Khas Penyelidikan FPEND Covid-19 (GG-2020-021)

\section{REFERENCES}

[1] Agung, S., Nurfina, A., Paidi, P., Tyasmiarni, C. \& Kusdianto, K. (2020). Effects of the Google Meet assisted method of learning on building student knowledge and learning outcomes. Universal Journal of Educational Research, 8(9): $3924-3936$.

[2] Al-Maroof, R. S., Alshurideh, M. T., Salloum, S. A., AlHamad, A. Q. M., \& Gaber, T. (2021). Acceptance of Google Meet during the spread of Coronavirus by Arab university students. In Informatics, 8(2): 24-41.

[3] Al-Maroof, R. S., Salloum, S. A., Hassanien, A. E. \& Shaalan, K. (2020). Fear from COVID-19 and technology adoption: The impact of Google Meet during Coronavirus pandemic. Interactive Learning Environments, 7(3): 1-16.

[4] Ali, S., Uppal, M. A. \& Gulliver, S. R. (2017). A conceptual framework highlighting e-learning implementation barriers. Information Technology \& People Journal, 31(1): 156-180.

[5] Aljohani, M. (2017). Principles of "constructivism" in foreign language teaching. Journal of Literature and Art Studies, 7(1): 97-107.

[6] Alsheail, A. (2010). Teaching English as a second/foreign language in a ubiquitous learning environment: A guide for ESL/EFL instructors. Disertasi Dr. Fal, California State University, Chico.

[7] Anshari, M., Almunawar, M. N., Shahrill, M., Wicaksono, D. K., \& Huda, M. (2017). Smartphones usage in the classrooms: Learning aid or interference?.Education and Information Technologies, 22(6): 3063-3079.

[8] Azilah, M. \& Ameer, H. (2020). Effects of post-pandemic Covid-19 pandemic in Malaysia. Archives of Business Review, 8(5): 201-210.

[9] Bailey, D. R. (2020). Learning from experience in the midst of Covid-19: Benefits, challenges and strategies in online teaching. Computer-Assisted Language Learning Electronic Journal, 21(2): 178-198.

[10] Bragazzi, N. L., Mansour, M., Bonsignore, A. \& Ciliberti, R. (2020). The role of hospital and community pharmacists in the management of COVID-19: Towards an expanded definition of the roles, responsibilities and duties of the pharmacist. Pharmacy, 8(3): 141-155.

[11] Bozkurt, A. \& Sharma, R. C. (2020). Emergency remote teaching in a time of global crisis due to Coronavirus pandemic. Asian Journal of Distance Education, 15(1): i-vi.

[12] Corbett, F., Fraizer, L., Madjidi, F. \& Sweeney, M. (2018). The rise of connectivist leadership. The IAFOR Research Archive. 
[13] Corbett, F. \& Spinello, E. (2020). Connectivism and leadership: harnessing a learning theory for the digital age to redefine leadership in the twenty-first century. Heliyon, 6(1): 250-259.

[14] Gleason, B. \& Heath, M. K. (2021). Injustice embedded in Google Classroom and Google Meet: A techno-ethical audit of remote educational technologies. Italian Journal of Educational Technology, 29(2): 26-41.

[15] Grapragasem, S., Krishnan, A. \& Azlin, M. N. (2014). Current trends in Malaysian higher education and the effect on education policy and practice: An overview. International Journal of Higher Education, 3(1): 85-93.

[16] Gilakjani, A. P. (2017). A review of the literature on the integration of technology into the learning and teaching of English language skills. International Journal of English Linguistics, 7(5): 95-106.

[17] Hiranrithikorn, P. (2019). Advantages and disadvantages of online learning In International Academic Multidisciplinary research Conference in Berlin 2019, 5(3): 14-17.

[18] Ironsi, C. S. (2021). Google Meet as a synchronous language learning tool for emergency online distant learning during the COVID-19 pandemic: Perceptions of language instructors and preservice teachers. Journal of Applied Research in Higher Education, 9(3): 18-36.

[19] Khairi, M. A. M., Faridah, I., Norsiah, H. \& Zaki, M. A. (2021). Preliminary study on readiness to teach online due to Covid19 pandemic among university academician in Malaysia. International Journal of Information and Education Technology, 11(5): 212-219.

[20] Kohnke, L. \& Moorhouse, B. (2020). Facilitating synchronous online language learning through Zoom. RELC Journal, 3(2): 23-43.

[21] Korpershoek, H., Harms, T., de Boer, H., van Kuijk, M. \& Doolaard, S. (2014). Effective classroom management strategies and classroom management programs for educational practice. Groningen.

[22] Lo, Y. Y. \& Melor, M. Y. (2021). Collaborative Tools in Enhancing ESL Writing during Covid 19: A Systematic Review. International Conference on Business Studies and Education (ICBE), 9(2): 10-19.

[23] Mattar, J. (2018). Constructivism and connectivism in education technology: Active, situated, authentic, experiential, and anchored learning. Revista Iberoamericana de Educación a Distancia, 21(2): 201-217.

[24] Mikusa, M. E. (2015). The effect of technology self-efficacy and personal engagement on students' and teachers' attitudes toward technology use in education. Disertasi Dr. Fal, Appalachian State University.

[25] Min, S., Shi, T. Y. \& Yang, H. K. (2020). Topical network embedding. Data Mining and Knowledge Discovery, 34(1): 75-100.

[26] Mishra, P., Pandey, C. M., Singh, U., Gupta, A., Sahu, C. \& Keshri, A. (2019). Descriptive statistics and normality tests for statistical data. Annals of cardiac anaesthesia, 22(1): 67-72.

[27] Mohammed, O., Mohamed, C. Y. \& Amel, N. (2018). Learning management system and the underlying learning theories. In Proceedings of the Mediterranean Symposium on Smart City Applications, 732-744.

[28] Mohammed, S. (2019). Technologic optimization of a virtual disease focused panel during the Covid pandemic and beyond. Abdominal Radiology, 46(7): 1-8.

[29] Mokhtar, A., Nor, A., H. \& Ameer, H. (2020). Development of post-pandemic Covid-19 higher education resilience framework in Malaysia. Archives of Business Review, 8(5): 201-210.

[30] Muhamad K. A., Airil, M. A. H., Ahmad, Y. A., Muhammad, A. M. K. \& Nurul, M. K. N. (2019). Using new technologies to teach English in Malaysia- issues and challenges. In Proceedings of the International Invention, Innovative \& Creative (InIIC) Conference, hlm. 203-207.

[31] Noor M. (2017). Students' academic performance and its relationship with their intrinsic and extrinsic motivation. Journal of Educational Research, 20(1): 74-82.

[32] Nur S. (2019). Factors impacting special education teachers' acceptance and actual use of technology. Education and Information Technologies, 24(3): 2035-2057.

[33] Olena, T. (2021). How to teach ESL online creatively? International Scientific Discussion: Problems, Tasks and Prospects, 8(1): 110-114.

[34] Purwanto, E. \& Tannady, H. (2020). The factors affecting intention to use Google Meet amid online meeting platforms competition in Indonesia. Technology Reports of Kansai University, 62(6): 2829-2838.

[35] Putu, N. R., Ely, T. \& Ninik, S. R. W. (2021). Teaching speaking of hotel room service information by using comic strip via Google Meet application. Journal of English Language Teaching, 8(1): 38-48.

[36] Rahman, S. F., Yunus, M. M. \& Hashim, H. (2019). An overview of flipped learning studies in Malaysia. Arab World English Journal (AWEJ), 10(4): 194-203.

[37] Rizal, P. W. (2021). Improving the students' motivation in learning English through Google Meet during the online learning. English Learning Innovation, 2(1): 35-42.

[38] Rusmawan, P. N., Trianasari, E. \& Wilujeng, N. S. R. (2021). Teaching speaking of hotel room service information by using comic strip via Google Meet application. Jo-ELT (Journal of English Language Teaching) Fakultas Pendidikan Bahasa \& Seni Prodi Pendidikan Bahasa Inggris IKIP, 8(1): 38-48.

[39] Silviska, I. A. \& Latifah, D. (2020). Google Meet as learning media for vocal techniques during the Covid-19 pandemic. In 3rd International Conference on Arts and Design Education (ICADE 2020), hlm. 281-283.

[40] Singh, R. \& Awasthi, S. (2020). Updated comparative analysis on video conferencing platforms - Zoom, Google Meet, Microsoft Teams, WebEx Teams and GoToMeetings. EasyChair Preprint, 4026.

[41] Singh, C. K. S., Singh, T. S. M., Ong, E. T., Thambu, N., Yusoff, M. Z. M., Moneyam, S. \& Abdullah, N. Y. (2020). Preservice teachers' perceptions of lecturers' teaching and learning strategies in Moral education. Universal Journal of Educational Research, 8(11B): 6307-6312.

[42] Siti, B. D. A., Ali, S., Ondrej, K., Petra, M. \& Ngoc, N. T. (2020). Digital learning demand for future education 4.0 - Case studies at Malaysia education institutions. In Informatics, 7(2): 13-23.

[43] Solanki, N. L. \& Shyamleel, I. M. (2012). Learning models and media employed by 7th grade English teachers. English Community Journal, 4(2): 122-132. 
[44] Sornasekaran, H., Mohammed, L. A. \& Amidi, A. (2020). Challenges associated with e-learning among ESL undergraduates in Malaysia: A conceptual framework. International Journal of Management and Human Science (IJMHS), 4(4): 30-38.

[45] Suhendi, A. \& Purwarno, N. (2018). Constructivist learning theory: The contribution to foreign language learning and teaching. KnE Social Sciences, 3(4): 87-95.

[46] Tamin, N. H. \& Mohamad, M. (2020). Google Classroom for teaching and learning in Malaysia primary school during Movement Control Order (MCO) due to Covid-19 pandemic. An International Online Journal, 20(2): 34-37.

[47] Teeroovengadum, V., Heeraman, N. \& Jugurnath, B. (2017). Examining the antecedents of ICT adoption in education using an extended technology acceptance model (TAM). International Journal of Education and Development using ICT, 13(3): 4-23.

[48] Ulla, M. B. (2018). English language teaching in Thailand: Filipino teachers' experiences and perspectives. Issues in Educational Research, 28(4): 1080-1094.

[49] Venkatesh, V. \& Bala, H. (2008). Technology acceptance model 3 and a research agenda on interventions. Decision Sciences, 39(2): 273-315.

[50] Weng, F., Yang, R. J., Ho, H. J. \& Su, H. M. (2018). A TAM-based study of the attitude towards use intention of multimedia among school teachers. Applied System Innovation, 1(3): 36-44.

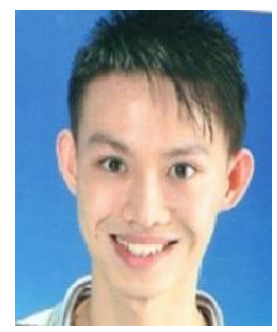

Winson Eng Wei Siang was born in Melaka in 1993. He obtained his Bachelor of Education (Hons) in the Teaching of English as a Second Language for primary education at International Languages Campus Teachers' Training Institute, Malaysia in 2016. He was posted to Pasir Gudang, Johor in 2017 where he embarked on his teaching journey. At present, he is serving at $\operatorname{SJK}(\mathrm{C})$ Ladang Grisek in Kota Masai, Pasir Gudang, Johor. In the meantime, he is pursuing his Master's Degree in National University Malaysia (UKM). He has also published some journal articles online. His areas of interest include linguistics and technology integration in the teaching of English as a Second Language.

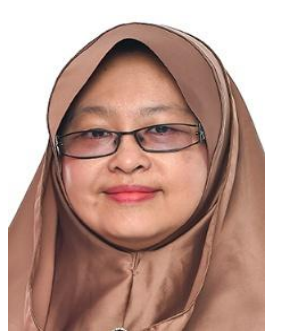

Maslawati Mohamad (Ph.D) was born in Johor, Malaysia. Currently, she is a senior lecturer at the Faculty of Education, Universiti Kebangsaan Malaysia. Her main research interests are innovations in teaching and learning in ESL context, Teaching Reading in ESL context, and English for Specific Purposes. Currently, she has published 101 journal articles including 30 Scopus articles, 55 proceedings, six book chapters and a book. She is also a reviewer for a few international journals and editor for a local journal. She graduated from Universiti Kebangsaan Malaysia and her area of specialization is Teaching English as a Second Language. She had also presented her research output locally and internationally in various seminars and conferences. 